\title{
Efficacy of 2-Hydroxypropyl- $\beta$-cyclodextrin in Niemann-Pick Disease Type C Model Mice and Its Pharmacokinetic Analysis in a Patient with the Disease
}

\author{
Yuta Tanaka ${ }^{a, \#}$ Yusei Yamada, ${ }^{a, \#}$ Yoichi Ishitsuka,${ }^{a}$ Muneaki Matsuo, ${ }^{b}$ Koki Shiraishi, ${ }^{a}$ \\ Koki Wada ${ }^{c}$ Yushiro Uchio, ${ }^{a}$ Yuki Kondo, ${ }^{a}$ Toru Takeo, ${ }^{d}$ Naomi Nakagata, ${ }^{d}$ Taishi Higashi, ${ }^{e}$ \\ Keiichi Motoyama, ${ }^{e}$ Hidetoshi Arima, ${ }^{e}$ Sakiko Mochinaga,${ }^{f}$ Katsumi Higaki, ${ }^{g}$ \\ Kousaku Ohno, ${ }^{h}$ and Tetsumi Irie ${ }^{*, a}$ \\ ${ }^{a}$ Department of Clinical Chemistry and Informatics, Graduate School of Pharmaceutical Sciences, Kumamoto \\ University; 5-1 Oe-honmachi, Chuo-ku, Kumamoto 862-0973, Japan: ${ }^{b}$ Department of Pediatrics, Faculty of \\ Medicine, Saga University; 5-1-1 Nabeshima, Saga 849-8501, Japan: ${ }^{c}$ Research Institute, Nihon Shokuhin Kako \\ Co., Ltd.; 30 Tajima, Fuji, Shizuoka 417-8530, Japan: ${ }^{d}$ Division of Reproductive Engineering, Center for Animal \\ Resources and Development (CARD), Kumamoto University; 2-2-1 Honjo, Chuo-ku, Kumamoto 860-0811, Japan: \\ ${ }^{e}$ Department of Physical Pharmaceutics, Graduate School of Pharmaceutical Sciences, Kumamoto University; \\ 5-1 Oe-honmachi, Chuo-ku, Kumamoto 862-0973, Japan: ${ }^{f}$ Department of Pharmacy, Faculty of Medicine, Saga \\ University; 5-1-1 Nabeshima, Saga 849-8501, Japan: ${ }^{g}$ Division of Functional Genomics, Research Center for \\ Bioscience and Technology, Faculty of Medicine, Tottori University; 86 Nishi-cho, Yonago, Tottori 683-8503, \\ Japan: and ${ }^{h}$ Sanin Rosai Hospital; 1-8-1 Kaikeshinden, Yonago, Tottori 683-8605, Japan.
}

Received October 20, 2014; accepted February 22, 2015

\begin{abstract}
Niemann-Pick type C disease (NPC), an autosomal recessive lysosomal storage disorder, is an inherited disease characterized by the accumulation of intracellular unesterified cholesterol. A solubilizing agent of lipophilic compounds, 2-hydroxypropyl- $\beta$-cyclodextrin (HPBCD), is an attractive drug candidate against NPC disease. However, establishment of the optimum dosage of HPBCD remains to be determined. In this study, we evaluated the effective dosage of HPBCD in NPC model $\left(\mathrm{Npcl}^{-/}\right)$mice, and determined serum HPBCD concentrations. Subcutaneous injection of $1000-4000 \mathrm{mg} / \mathrm{kg}$ HPBCD improved the lifespan of $\mathrm{Npcl}^{-/-}$mice. In addition, liver injury and cholesterol sequestration were significantly prevented by $4000 \mathrm{mg} / \mathrm{kg} \mathrm{HPBCD}$ in $\mathrm{Npcl}^{-/-}$mice. Serum HPBCD concentrations, when treated at the effective dosages $(1000-4000 \mathrm{mg} / \mathrm{kg})$, were approximately $1200-2500 \mu \mathrm{g} / \mathrm{mL}$ at $0.5 \mathrm{~h}$ after subcutaneous injection, and blood HPBCD concentrations were immediately eliminated in $\mathrm{Npcl}^{-/-}$mice. Furthermore, we examined serum HPBCD concentrations when treated at $40000 \mathrm{mg}$ (approximately $2500 \mathrm{mg} / \mathrm{kg}$ ) in a patient with $\mathrm{NPC}$. We observed that the effective concentration in the in vivo study using $\mathrm{Npcl}^{-1-}$ mice was similar to that in the patient. In the patient, systemic clearance and the volume of distribution of HPBCD were in accordance with the glomerular filtration rate and extracellular fluid volume, respectively. These results could provide useful information for developing the optimal dosage regimen for HPBCD therapy when administered intravenously to NPC patients.
\end{abstract}

Key words Niemann-Pick type C; 2-hydroxypropyl- $\beta$-cyclodextrin; Npcl-deficient mouse

Niemann-Pick type C (NPC) disease is a fatal, progressive, and autosomal recessive disorder caused by mutations in either the $\mathrm{NPC1}$ (95\% of cases) or NPC2 gene. ${ }^{1-3)}$ Symptoms of NPC disease include severe progressive neurodegeneration and enlargement of the liver. ${ }^{3,4)}$ NPC1 protein, localized in late endosomes/lysosomes, has a sterol-sensing domain, and plays an important role in cellular cholesterol transport. ${ }^{5,6)}$ Marked lysosomal accumulation of unesterified cholesterol and a shortage of esterified cholesterol in other cellular compartments are observed in the cells of NPC patients. Cholesterol sequestration appears to be an important factor in developing NPC disease. A cyclic oligosaccharide, 2-hydroxypropyl- $\beta$ cyclodextrin (HPBCD), is used as an enabling excipient in pharmaceutical formulations, as well as a cholesterol modifier in the body. Some reports have shown that HPBCD improves cholesterol sequestration in organs and prolongs the lifespan in $\mathrm{Npcl}$ null mice, suggesting that HPBCD is a promising drug candidate against NPC disease. ${ }^{7-10)}$

\footnotetext{
${ }^{\#}$ These authors contributed equally to this work.

* To whom correspondence should be addressed. e-mail: tirie@gpo.kumamoto-u.ac.jp
}

Recently, Matsuo et $a l^{4)}$ reported the effectiveness of HPBCD in treatment of two Japanese patients with NPC disease. One patient was started with intravenous infusion of $80 \mathrm{mg} / \mathrm{kg} \mathrm{HPBCD}$ for $8 \mathrm{~h}$ twice a week, and another patient was started with $80 \mathrm{mg} / \mathrm{kg}$ HPBCD for $8 \mathrm{~h}$ three times a week. This dose of HPBCD was gradually increased to approximately $2000 \mathrm{mg} / \mathrm{kg}$ or $2500 \mathrm{mg} / \mathrm{kg}$. HPBCD was partially effective in improving hepatosplenomegaly and central nervous system dysfunction, although HPBCD did not improve their neurological deficits. However, little is known regarding pharmacokinetic information, such as effective serum HPBCD concentrations, systemic clearance, and volume of distribution, in NPC patients, and even in NPC model mice.

Pharmacodynamic and pharmacokinetic information is essential for establishing the appropriate dosage regimen of HPBCD for treatment of NPC. We conducted this study to evaluate the effective dose of HPBCD in NPC model mice, and determined serum HPBCD concentrations when the effective dose of HPBCD was administered to NPC model mice. Furthermore, we measured serum HPBCD concentrations 
during intravenous infusion in a patient with NPC, and also estimated the pharmacokinetic parameters of HPBCD.

\section{MATERIALS AND METHODS}

Reagents HPBCD (average degree of substitution [DS]: 4.7) that was used for mice experiments was kindly donated by Nihon Shokuhin Kako Co., Ltd. (Tokyo, Japan). HPBCD (Kleptose-HPB) that was used for intravenous treatment for a patient was purchased from Roquette Japan K.K. (Tokyo, Japan). A cholesterol detection reagent, Determiner L FC, was kindly donated by Kyowa Medex Co., Ltd. (Tokyo, Japan). A solution of $10 \%$ neutral buffered formalin was obtained from Wako Pure Chemical Industries, Ltd. (Osaka, Japan). Mayer's hematoxylin, $1 \%$ eosin alcohol solution, and mounting medium for histological examination (malinol) were purchased from Muto Pure Chemicals (Tokyo, Japan). All other reagents and solvents were of reagent grade. De-ionized and distilled bio-pure grade water was used throughout the study.

Animal Experiments Male and female homozygous $\left(N p c 1^{-/-}\right)$mutant (BALB/cNctr- $\left.N p c 1^{\mathrm{m} 1 \mathrm{~N}}\right)$ mice ${ }^{11,12)}$ were used as NPC model mice. Age-matched wild-type $\left(\mathrm{Npcl}^{+/+}\right)$and heterozygous mutant $\left(\mathrm{Npcl}^{+/-}\right)$mice were used as control mice. Mice were housed in cages in a room under controlled conditions at $24^{\circ} \mathrm{C}$ with a 12-h light cycle, and provided with free access to food and water. A total of $168 \mathrm{Npcl}^{-1-}$, $6 \mathrm{Npcl}^{+/-}$and $6 \mathrm{Npcl}^{+/+}$mice were used in this study. The effects of HPBCD on manifestation of NPC in mice were evaluated by examining survival. We also performed biological and histological analyses, such as measurements of cholesterol content in the liver, relative liver weight to body weight, liver pathohistology, and serum alanine transaminase (ALT) levels. All experimental procedures conformed to the animal use guidelines of the Committee for Ethics on Animal Experiments of Kumamoto University (approval numbers M24-367 and F25-306). The mice were bred and kept in specific pathogen-free conditions in the Center for Animal Resources and Development, Kumamoto University. The animal experiments were performed at the Department of Clinical Chemistry and Informatics, Graduate School of Pharmaceutical Sciences, Kumamoto University.

Effects of HPBCD on Survival in $\mathrm{Npcl}^{-1-}$ Mice A total of 78 age-matched (6 weeks old) $\mathrm{Npcl}^{-/-}$mice were divided into the following six groups: (1) the saline group that was treated with saline $(20 \mu \mathrm{L} / \mathrm{g})(n=16 ; 9$ males and 7 females); (2) $400 \mathrm{mg} / \mathrm{kg}$ group that was treated with $400 \mathrm{mg} /$ $\mathrm{kg}$ of HPBCD ( $n=10 ; 5$ males and 5 females); (3) $1000 \mathrm{mg} / \mathrm{kg}$ group that was treated with $1000 \mathrm{mg} / \mathrm{kg}$ of $\operatorname{HPBCD}(n=12 ; 6$ males and 6 females); (4) $2000 \mathrm{mg} / \mathrm{kg}$ group that was treated with $2000 \mathrm{mg} / \mathrm{kg}$ of HPBCD ( $n=16 ; 8$ males and 8 females); (5) $4000 \mathrm{mg} / \mathrm{kg}$ group that was treated with $4000 \mathrm{mg} / \mathrm{kg}$ of HPBCD ( $n=10 ; 5$ males and 5 females); and (6) $20000 \mathrm{mg} / \mathrm{kg}$ group that was treated with $20000 \mathrm{mg} / \mathrm{kg}$ of $\operatorname{HPBCD}(n=14$; 7 males and 7 females). HPBCD was dissolved in water and adjusted to $\mathrm{pH}$ 7.4. HPBCD was administered by subcutaneous injection through the back of the neck in mice. The injection volume of HPBCD solution was set at $20 \mu \mathrm{L} / \mathrm{g}$ in all of the HPBCD-treated groups. We measured the body weight of mice and treated the mice with HPBCD once a week during the life-span. The doses of $0-4000 \mathrm{mg} / \mathrm{kg}$ HPBCD used in this study were selected based on previous reports. ${ }^{7-9)}$ In addition, the upper dose $(20000 \mathrm{mg} / \mathrm{kg})$ of HPBCD does not have any adverse effects in acute toxicity in $\mathrm{Npcl}^{-/-}$mice, as found in our previous study. ${ }^{12)}$

Effects of HPBCD on Biological and Histological Parameters in $\mathrm{Npcl}^{-1-}$ Mice A total of 36 age-matched (6 weeks old) $\mathrm{Npcl}^{-1-}$ mice were divided into the following six groups: (1) the saline group that was treated with saline $(20 \mu \mathrm{L} / \mathrm{g})$ ( $n=6 ; 3$ males and 3 females); (2) $400 \mathrm{mg} / \mathrm{kg}$ group that was treated with $400 \mathrm{mg} / \mathrm{kg}$ of HPBCD $(n=6 ; 3$ males and $3 \mathrm{fe}-$ males); (3) $1000 \mathrm{mg} / \mathrm{kg}$ group that was treated with $1000 \mathrm{mg} /$ $\mathrm{kg}$ of HPBCD ( $n=6 ; 3$ males and 3 females); (4) $2000 \mathrm{mg} / \mathrm{kg}$ group that was treated with $2000 \mathrm{mg} / \mathrm{kg}$ of HPBCD $(n=6 ; 3$ males and 3 females); (5) $4000 \mathrm{mg} / \mathrm{kg}$ group that was treated with $4000 \mathrm{mg} / \mathrm{kg}$ of HPBCD $(n=6 ; 3$ males and 3 females); and (6) $20000 \mathrm{mg} / \mathrm{kg}$ group that was treated with $20000 \mathrm{mg} /$ $\mathrm{kg}$ of HPBCD $(n=6 ; 3$ males and 3 females). We treated 6-week-old NPC mice with HPBCD or saline once a week until 8.5 weeks of age by subcutaneous injection (3 injections in total). The injection volume of HPBCD solution was set at $20 \mu \mathrm{L} / \mathrm{g}$ in all of the HPBCD-treated groups. In addition, male and female age-matched (6 weeks old) $\mathrm{Npcl}^{+/+}$and $\mathrm{Npcl}^{+/-}$ mice were used as controls. Finally, another two groups, the $\mathrm{NpCl}^{+/+}$saline group ( $n=6 ; 3$ males and 3 females) and the $\mathrm{Npcl}^{+/-}$saline group ( $n=6 ; 3$ males and 3 females), were included. These mice were treated with saline $(20 \mu \mathrm{L} / \mathrm{g})$ once a week until 8.5 weeks of age by subcutaneous injection ( 3 injections in total).

Following the final injection, all of the mice were euthanized, and blood and organ samples were collected. Blood samples were collected from the inferior vena cava. The blood samples were centrifuged at $4000 \times \boldsymbol{g}$ at $4^{\circ} \mathrm{C}$ for $10 \mathrm{~min}$ after coagulation, and serum was collected for measurement of ALT levels. Sera were stored at $-30^{\circ} \mathrm{C}$ until further analysis. ALT levels were measured by a biochemical analyzer (Hitachi 7170, Hitachi, Tokyo, Japan).

Liver samples were immediately weighed and a portion of the hepatic lobes was immediately stored at $-80^{\circ} \mathrm{C}$ until cholesterol measurements. Tissue homogenates were prepared in buffer $(20 \mathrm{~mm}$ Tris, $2 \mathrm{~mm}$ ethylenediaminetetraacetic acid (EDTA), $150 \mathrm{~mm} \mathrm{NaCl}$, and $1 \%$ TritonX-100, $\mathrm{pH} 8$ ) and centrifuged for $10 \mathrm{~min}$ at $10000 \times \boldsymbol{g}$ at $4^{\circ} \mathrm{C}$. The supernatant was removed and the pellet was collected. The pellet was dissolved in phosphate buffered saline (PBS) and aliquoted into two samples. One aliquot was incubated with cholesterol esterase at $37^{\circ} \mathrm{C}$ for $30 \mathrm{~min}$. The cholesterol content in these samples was measured by the Determiner L FC (Kyowa Hakko Kirin Co., Ltd., Tokyo, Japan) according to the manufacturer's protocol. Other hepatic lobes were immediately fixed in $10 \%$ neutral buffered formalin and then embedded in paraffin. Microtome sections, $3 \mu \mathrm{m}$ thick, were prepared and stained with hematoxylin-eosin (H\&E). Histopathological changes in the liver were photographed and analyzed using a microscopic system (Biorevo BZ-9000; Keyence Co., Osaka, Japan). The results were evaluated in an unblinded manner. We also estimated the ratio of liver weight to body weight as a measure of enlargement of the liver.

Measurement of Serum HPBCD Concentrations in $\mathrm{Npcl}^{-1-}$ Mice A total of 54 age-matched (8 weeks old) $\mathrm{Npcl}^{-1-}$ mice were divided into three groups (1-3), with each group having three subgroups (A-C): (1-A) $1000 \mathrm{mg} / \mathrm{kg} 0.5 \mathrm{~h}$ after group, where $1000 \mathrm{mg} / \mathrm{kg}$ of $\mathrm{HPBCD}$ was administered 
and the concentration measured at $0.5 \mathrm{~h}$ after the treatment ( $n=6$; male 3 and female 3); (1-B) $1000 \mathrm{mg} / \mathrm{kg} 1 \mathrm{~h}$ after group, where $1000 \mathrm{mg} / \mathrm{kg}$ of HPBCD was administered and the concentration measured at $1 \mathrm{~h}$ after the treatment $(n=6$; male 3 and female 3); (1-C) $1000 \mathrm{mg} / \mathrm{kg} 2 \mathrm{~h}$ after group, where $1000 \mathrm{mg} / \mathrm{kg}$ of HPBCD was administered and the concentration measured at $2 \mathrm{~h}$ after the treatment $(n=6$; male 3 and female 3); (2-A) $2000 \mathrm{mg} / \mathrm{kg} 0.5 \mathrm{~h}$ after group, where $2000 \mathrm{mg} /$ $\mathrm{kg}$ of HPBCD was administered and the concentration measured at $0.5 \mathrm{~h}$ after the treatment $(n=6$; male 3 and female 3); (2-B) $2000 \mathrm{mg} / \mathrm{kg} 1 \mathrm{~h}$ after group, where $2000 \mathrm{mg} / \mathrm{kg}$ of HPBCD was administered and the concentration measured at $1 \mathrm{~h}$ after the treatment ( $n=6$; male 3 and female 3$)$; (2-C) $2000 \mathrm{mg} / \mathrm{kg} 2 \mathrm{~h}$ after group, where $2000 \mathrm{mg} / \mathrm{kg}$ of HPBCD was administered and the concentration measured at $2 \mathrm{~h}$ after the treatment ( $n=6$; male 3 and female 3); (3-A) $4000 \mathrm{mg} / \mathrm{kg}$ $0.5 \mathrm{~h}$ after group, where $4000 \mathrm{mg} / \mathrm{kg}$ of HPBCD was administered and the concentration measured at $0.5 \mathrm{~h}$ after the treatment ( $n=6$; male 3 and female 3); (3-B) $4000 \mathrm{mg} / \mathrm{kg} 1 \mathrm{~h}$ after group, where $4000 \mathrm{mg} / \mathrm{kg}$ of HPBCD was administered and the concentration measured at $1 \mathrm{~h}$ after the treatment $(n=6$; male 3 and female 3); (3-C) $4000 \mathrm{mg} / \mathrm{kg} 2 \mathrm{~h}$ after group, where $4000 \mathrm{mg} / \mathrm{kg}$ of HPBCD was administered and the concentration measured at $2 \mathrm{~h}$ after the treatment $(n=6$; male 3 and female 3). Mice were euthanized at each time of measurement and blood samples were collected from the inferior vena cava. Blood samples were centrifuged at $4000 \times \boldsymbol{g}$ at $4^{\circ} \mathrm{C}$ for $10 \mathrm{~min}$ after coagulation, and serum was collected for measurement of HPBCD. HPBCD concentrations were determined by the procedure described in next section (below).

Measurement of Serum HPBCD Concentrations in an NPC Patient We measured serum HPBCD concentrations in an NPC patient during intravenous HPBCD therapy. Detailed information of the patient and the therapeutic process have been previously described. ${ }^{4)}$ In brief, the patient, a 4-year-old girl in whom hepatosplenomegaly was detected before birth, was diagnosed as having NPC based on mutations in the NPC1 gene (c.581_592delinsG, Y1088C). Hepatosplenomegaly was present before starting HPBCD intravenous therapy. The patient could walk indoors with assistance and speak a few unclear words. She exhibited vertical gaze palsy, mild occasional dysphagia, slight hypotonia, ataxia and frequent attacks of cataplexy, and rare convulsions. HPBCD treatment was performed according to the Addi and Cassi HPBCD compassionate use clinical study protocol (Protocol Extension 1.0, 7 July 2009), kindly provided by Chris Hempel (http:// addiandcassi.com/). HPBCD (Kleptose-HPB, Roquette Japan K.K.) was dissolved in distilled water at a concentration of $20 \%(\mathrm{w} / \mathrm{v})$ and diluted to the required concentration with saline prior to infusion. HPBCD infusions were started after informed consent had been obtained from the parents. She initially had $80 \mathrm{mg} / \mathrm{kg}$ HPBCD per dose, infused over a period of $8 \mathrm{~h}$, thrice weekly. This dose of HPBCD was gradually increased to approximately $2500 \mathrm{mg} / \mathrm{kg}$ per dose. As reported previously, ${ }^{4)}$ intravenous treatment of HPBCD was effective in improving hepatosplenomegaly after 4 months of treatment. Assessment of serum HPBCD concentrations was performed at 8 months of treatment. Blood samples were collected at 2, 8 , and $12 \mathrm{~h}$ after the start of HPBCD infusion. This study was approved by the Ethics Committees of Saga University (no. 2009-05-04) and Kumamoto University (nos. 608 and 879).
The therapeutic intervention was performed at Saga University Hospital.

Determination of Serum HPBCD Concentrations Measurement of serum HPBCD concentrations was performed according to the method reported by Frijlink et al. ${ }^{13)}$ and Szathmary. ${ }^{14)}$ The high-performance liquid chromatography (HPLC) equipment consisted of two LC-10AT pumps, an SIL$10 \mathrm{~A}_{\mathrm{XL}}$ auto injector, an SPD-10A UV-Vis detector, a CBM$10 \mathrm{~A}$ communications bus module, and a CTO-10AC column oven (Shimadzu Corporation, Kyoto, Japan). The HPLC column, OHpak SB-802 HQ (Showa Denko K.K., Tokyo, Japan), was used at $50^{\circ} \mathrm{C}$. One LC10-A pump was used for delivering column eluent to the HPLC column and the other pump was for supply of post-column reagent after passing through the HPLC column. Capillary tubing of approximately $10 \mathrm{~m}$ (internal diameter: $1.0 \mathrm{~mm}$ ) was used for mixing the column eluent with the post-column reagent before the detector. The post-column reagent was prepared by adding $10 \mathrm{~mL}$ of $6 \mathrm{~mm}$ phenolphthalein ethanol solution to $990 \mathrm{~mL}$ of $8 \mathrm{~mm}$ sodium bicarbonate aqueous solution, and this was adjusted to $\mathrm{pH}$ 10.5 by $1 \mathrm{~m}$ sodium hydroxide. The column eluent was $0.9 \%$ sodium chloride solution that was adjusted to $\mathrm{pH} 4.3$ by acetic acid. The detector was set at $546 \mathrm{~nm}$. A total of $40 \mu \mathrm{L}$ of $20 \%$ trichloroacetic acid solution was added to $100 \mu \mathrm{L}$ of plasma sample and carefully mixed. After mixing and centrifugation for $5 \mathrm{~min}\left(10000 \times \mathbf{g}, 4^{\circ} \mathrm{C}\right), 40 \mu \mathrm{L}$ of $1 \mathrm{M}$ sodium carbonate solution was added to $80 \mu \mathrm{L}$ of the supernatant. The sample was shaken and passed through a filter (Millex-HP PES $0.45 \mu \mathrm{m}$; Merck KGaA, Darmstadt, Germany) and $10 \mu \mathrm{L}$ of filtrated sample was injected into the HPLC column. The flow rate of the column eluent was $0.6 \mathrm{~mL} / \mathrm{min}$ and the flow rate of the post-column reagent was $0.6 \mathrm{~mL} / \mathrm{min}$. The retention time of HPBCD was approximately $14 \mathrm{~min}$. The peak height was used to calculate HPBCD concentrations based on calibration curves of saline spiked with HPBCD.

Statistical Analysis Statistical analysis was performed using GraphPad Prism ver. 5.01 (GraphPad Software, San Diego, CA, U.S.A.). Survival data were analyzed using the Kaplan-Meier method, and the log-rank test was used to compare statistical significances. Multiple comparisons were performed to examine the statistical significance of the results. When uniform variance of the results was identified by Bartlett's analysis $(p<0.05)$, one-way ANOVA was used to test for statistical differences. When significant differences $(p<0.05)$ were identified, the results were further analyzed by Tukey's (Tukey-Kramer) multiple range test or Bonferroni's multiple comparison test for significant differences among the values. If uniform variance of the results was not identified, non-parametric multiple comparisons were performed. After confirming significant differences $(p<0.05)$ using KruskalWallis analysis, the differences were then examined by applying Dunn's multiple test.

\section{RESULTS}

Effects of HPBCD on Survival Time and Changes in Body Weight in $\mathrm{Npcl}^{-/-}$Mice First, we examined the dose responsiveness of the effects of HPBCD treatment on the lifespan of $\mathrm{Npcl}^{-/-}$mice. In the saline-treated (control) group, all of the mice died within $83 \mathrm{~d}$ and the median survival time was $77 \mathrm{~d}$. A significant effect was not observed with $400 \mathrm{mg} / \mathrm{kg}$ HPBCD 


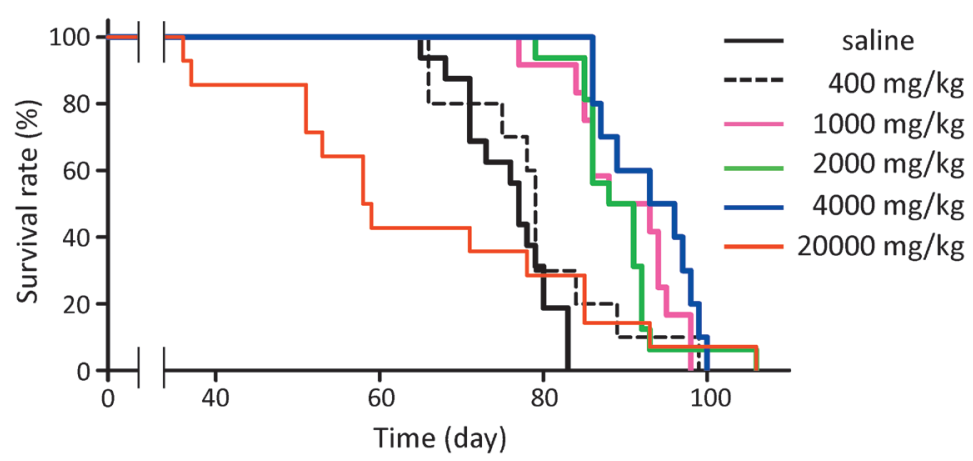

Fig. 1. Effect of HPBCD Injection on the Survival Rate of $\mathrm{Npcl}$ Null $\left(\mathrm{Npcl}^{-/-}\right)$Mice

Seventy-eight $\mathrm{Npcl}^{-/-}$mice were divided into the following six groups: (1) saline group; (2) $400 \mathrm{mg} / \mathrm{kg}$ group; (3) $1000 \mathrm{mg} / \mathrm{kg}$ group; (4) $2000 \mathrm{mg} / \mathrm{kg}$ group; (5) $4000 \mathrm{mg} /$ $\mathrm{kg}$ group; and (6) $20000 \mathrm{mg} / \mathrm{kg}$ group. Mice were subcutaneously treated with HPBCD once a week, and survival was monitored every day. Significant differences were observed among the 1000,2000 , and $4000 \mathrm{mg} / \mathrm{kg}$ groups compared with the saline group $(p<0.001) . n=10-16$.

treatment (median survival, 79d) compared with saline. However, 1000,2000 , and $4000 \mathrm{mg} / \mathrm{kg}$ HPBCD significantly prolonged survival time in mice compared with the saline group (Fig. 1). The median survival was 90,89 , and $94 \mathrm{~d}$ in the 1000,2000 , and $4000 \mathrm{mg} / \mathrm{kg}$ groups, respectively. There was no significant difference in survival between the $20000 \mathrm{mg} / \mathrm{kg}$ - group (median survival, 58d) compared with the saline group. However, some mice treated with $20000 \mathrm{mg} / \mathrm{kg}$ died in the early stage of treatment (40-60 d). Two mice in the $20000 \mathrm{mg} / \mathrm{kg}$ group lived for a long time (approximately 90-100 d).

Effects of HPBCD on Biological and Histological Parameters in $\mathrm{Npcl}^{-1-}$ Mice We then examined the dose responsiveness of the effects of HPBCD treatment on biological and histological parameters in $\mathrm{Npcl}^{-/-}$mice. The ratio of liver to body weight and serum ALT levels were significantly higher in $\mathrm{Npcl}^{-/-}$mice compared with $\mathrm{Npcl}^{+/+}$and $\mathrm{Npcl}^{+/-}$mice groups (Figs. 2A, B). These high ratios of liver to body weight and serum ALT levels were attenuated by HPBCD treatment in a dose-dependent manner. Statistical significance was observed in the ratio of liver to body weight in the $4000 \mathrm{mg} / \mathrm{kg}$ group compared with the $\mathrm{Npcl}^{-/-}$saline group (Fig. 2A). Significant lowering effects in serum ALT levels were observed in the 2000 and $4000 \mathrm{mg} / \mathrm{kg}$ groups (Fig. 2B). However, there were no significant differences in the ratio of liver to body weight and serum ALT levels in the $20000 \mathrm{mg} / \mathrm{kg}$ group compared with the $\mathrm{Npcl}^{-/-}$saline group.

Total cholesterol content in the liver was higher in $\mathrm{Npcl}^{-/-}$ mice compared with $\mathrm{Npcl}^{+/+}$and $\mathrm{Npcl}^{+/-}$mice. This high total cholesterol content in $\mathrm{Npcl}^{-/-}$mice was dose-dependently prevented by HPBCD treatment (Fig. 2C). Although there was little effect of $400 \mathrm{mg} / \mathrm{kg}$ treatment on total cholesterol content, significant effects were observed in the other HPBCD-treated groups. The fraction of esterified cholesterol in the liver was lower in $\mathrm{Npcl}^{-/-}$mice compared with $\mathrm{Npcl}^{+/+}$ and $\mathrm{Npcl}^{+/-}$mice (Fig. 2D). Treatment with HPBCD increased the fraction of esterified cholesterol in the $\mathrm{Npcl}^{-/-}$liver in a dose-dependent manner. Statistical significance was observed in the $4000 \mathrm{mg} / \mathrm{kg}$ group compared with the $\mathrm{Npcl}^{-1-}$ saline group. Representative pathohistological images are shown in Fig. 2E. Extensive vacuolated hepatocytes and Kupffer cells were observed in histological sections of saline-treated $\mathrm{Npcl}^{-/-}$mice compared with $\mathrm{Npcl}^{+/+}$and $\mathrm{Npcl}^{+/-}$mice. These pathohistological changes were dose-dependently attenuated in the HPBCD treatment groups. Although vacuolated hepatocytes and Kupffer cells were also reduced in the HPBCD treatment groups, hepatocellular necrosis was observed in the $20000 \mathrm{mg} / \mathrm{kg}$ group.

Changes in Serum HPBCD Concentrations in $\mathrm{Npcl}^{-1-}$ Mice We examined the changes in serum HPBCD concentrations after HPBCD treatment (1000, 2000, and $4000 \mathrm{mg} /$ $\mathrm{kg}$ ) in $\mathrm{Npcl}^{-/-}$mice. As shown in Fig. 3, serum HPBCD concentrations were approximately 1200,2000 , and $2500 \mu \mathrm{g} / \mathrm{mL}$ at $0.5 \mathrm{~h}$ after administration of 1000,2000 , and $4000 \mathrm{mg} / \mathrm{kg}$, respectively. Serum HPBCD concentrations were immediately reduced with time and were approximately $400-1600 \mu \mathrm{g} / \mathrm{mL}$ (0.29-1.14 mm) at $2 \mathrm{~h}$ after HPBCD injection.

Changes in Serum HPBCD Concentrations Following Intravenous Infusion to a Patient with NPC We measured serum HPBCD concentrations to evaluate pharmacokinetic characteristics of HPBCD in an NPC patient. The NPC patient (female, 5 years old, body height was $105 \mathrm{~cm}$, and weight was $15.1 \mathrm{~kg}$ ) was treated with HPBCD $(40000 \mathrm{mg}$, intravenously administered for $8 \mathrm{~h}$ ), and serum was collected at 2, 8, and $12 \mathrm{~h}$ after the start of the infusion. As shown in Fig. 4, serum HPBCD concentrations were 1295,1756 , and $90 \mu \mathrm{g} / \mathrm{mL}$ at 2 , 8 , and $12 \mathrm{~h}$ after the start of infusion. Serum HPBCD concentrations appeared to immediately begin to decrease with time after the end of HPBCD administration. The estimated pharmacokinetic parameters of the patient based on these values of serum HPBCD concentrations were as follows: systemic clearance, $198 \mathrm{~mL} / \mathrm{h} / \mathrm{kg}$; volume of distribution, $266 \mathrm{~mL} / \mathrm{kg}$; and elimination half-life, $0.92 \mathrm{~h}$. The graph in Fig. 4 shows the theoretical curve, assuming that HPBCD is rapidly distributed in the extracellular fluid, and then excreted at the rate of glomerular filtration, even in the patient with NPC. All three serum HPBCD concentrations that were observed in the NPC patient provided a good fit of the theoretical curve well (Fig. 4).

\section{DISCUSSION}

This study aimed to evaluate the effective dosage of HPBCD that can improve the survival time of $\mathrm{Npcl}^{-1-}$ mice, and to measure serum HPBCD concentrations when treated with $\mathrm{HPBCD}$ in $\mathrm{Npcl}^{-1-}$ mice. In addition, we determined serum HPBCD concentrations in an NPC patient who received intravenous HPBCD infusion and evaluated the pharmacokinetic characteristics of HPBCD in this patient. First, we showed that treatment of 1000,2000 , or $4000 \mathrm{mg} / \mathrm{kg}$ HPBCD (subcutaneously, once a week) significantly improved survival. All liver function parameters (unesterified and esterified cho- 
A

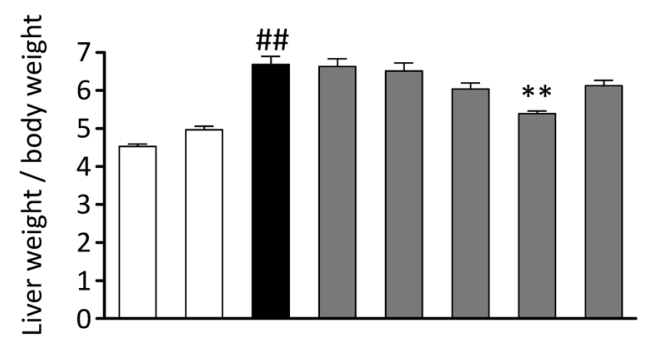

$\mathrm{HPBCD}(\mathrm{mg} / \mathrm{kg}) \quad 0 \quad 0 \quad 0 \quad 40010002000400020000$

Npc1 genotype +/+ +/-

C

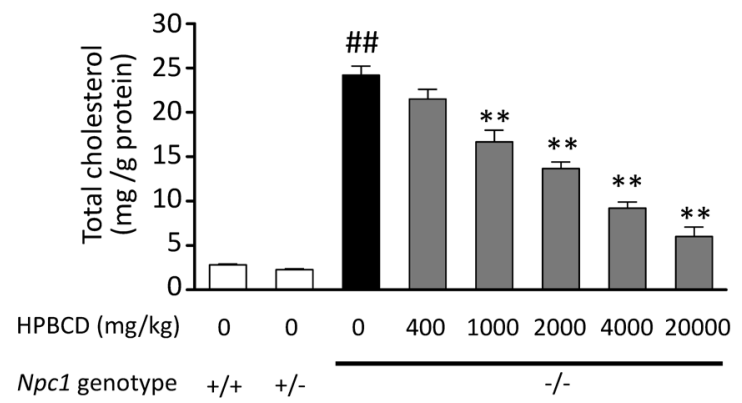

B

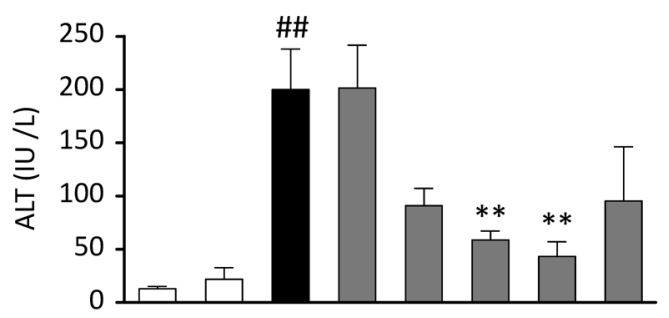

$\mathrm{HPBCD}(\mathrm{mg} / \mathrm{kg}) \quad 0 \quad 0 \quad 0 \quad 400 \quad 10002000400020000$

Npc1 genotype + /+ +/-

D
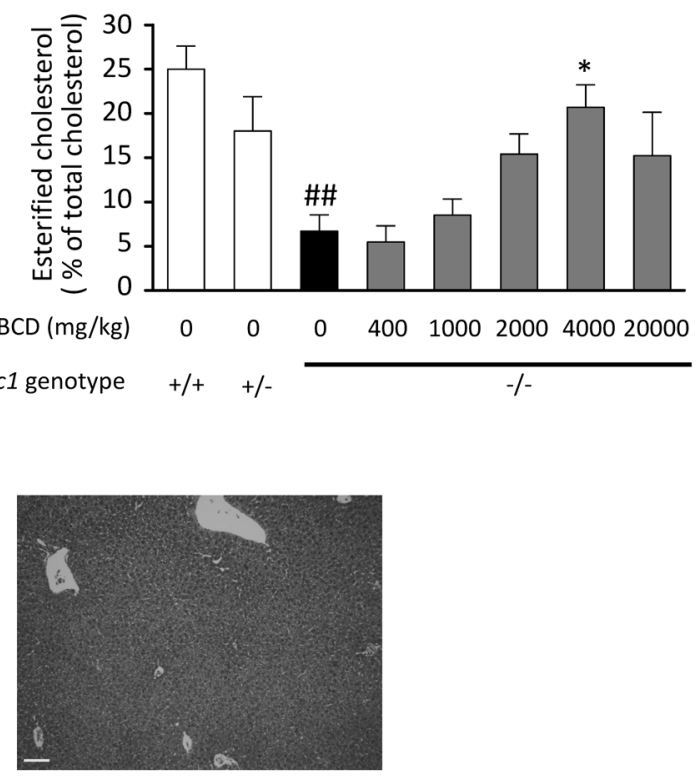

Npc1 ${ }^{+1-}$

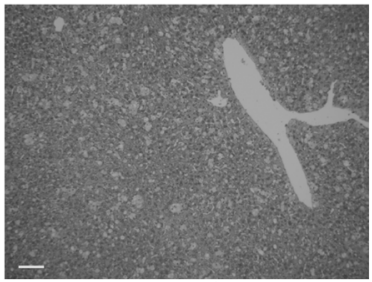

Npc1 $1^{-1}$

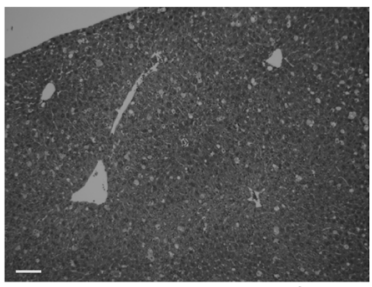

+ HPBCD 2000 mg/kg

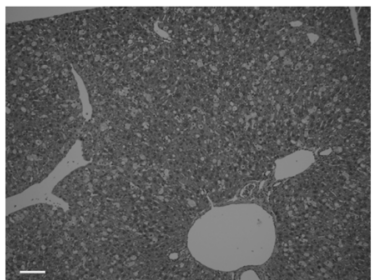

+ HPBCD $400 \mathrm{mg} / \mathrm{kg}$

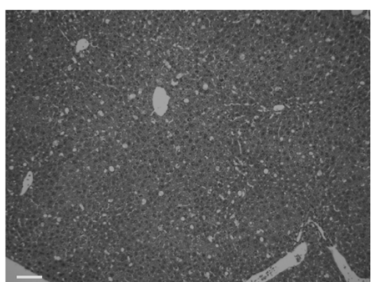

+ HPBCD 4000 mg $/ \mathrm{kg}$

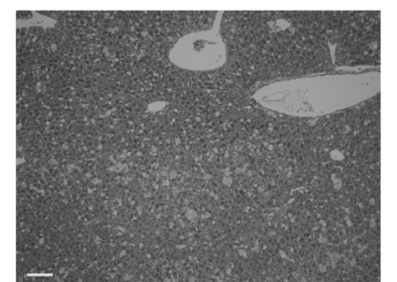

+ HPBCD $1000 \mathrm{mg} / \mathrm{kg}$

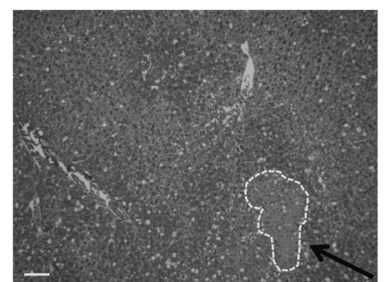

+ HPBCD 20000 mg/kg

Fig. 2. Dose Responsiveness of the Effects of HPBCD and Images of Hepatic Sections

Dose responsiveness of the effects of HPBCD on (A) liver/body weight ratio, (B) serum ALT levels, (C) total cholesterol content, and (D) percentage of esterified cholesterol in liver tissue. (E) Representative images of hepatic sections in $\mathrm{Npcl}^{-/-}$mice. $\mathrm{Npcl}^{+/+}$and $\mathrm{Npcl}^{+/-}$mice were used as control animals. $\mathrm{Npcl}^{-/-}$mice were divided into the following groups: (1) $\mathrm{Npcl}^{-/-}$saline group; (2) $400 \mathrm{mg} / \mathrm{kg}$ group; (3) $1000 \mathrm{mg} / \mathrm{kg}$ group; (4) $2000 \mathrm{mg} / \mathrm{kg}$ group; (5) $4000 \mathrm{mg} / \mathrm{kg}$ group; (6) $20000 \mathrm{mg} / \mathrm{kg}$ group; (7) $\mathrm{Npcl}^{+/+}$saline group; and (8) $\mathrm{Npcl}^{+/-}$saline group. We treated 6-week-old NPC mice with HPBCD or saline once a week until 8.5 weeks of age by subcutaneous injection ( 3 injections in total). Histological sections were stained with H\&E. The arrow shown in the picture of HPBCD $20000 \mathrm{mg} / \mathrm{kg}$ treated group indicates hepatocellular necrosis. Scale bar: $100 \mu \mathrm{m} .{ }^{*} p<0.05, * * p<0.01$ compared with the $N p c 1^{-/-}$saline group. ${ }^{\# \#} p<0.01$ compared with the $N p c I^{+/+}$saline group. Each bar represents the mean \pm S.E. $(n=6)$. 
$1000 \mathrm{mg} / \mathrm{kg}$

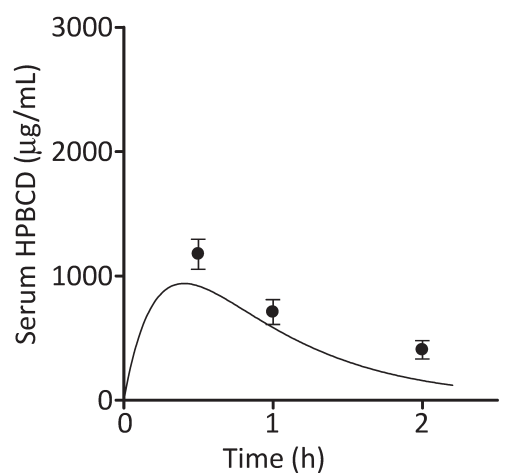

$2000 \mathrm{mg} / \mathrm{kg}$

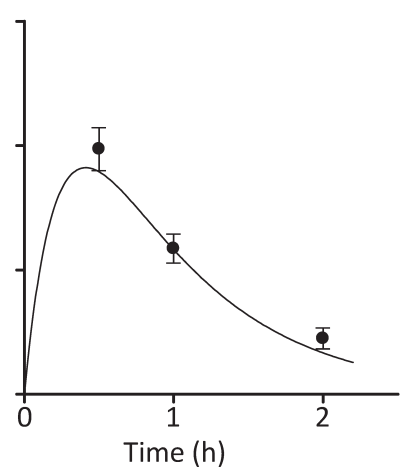

$4000 \mathrm{mg} / \mathrm{kg}$

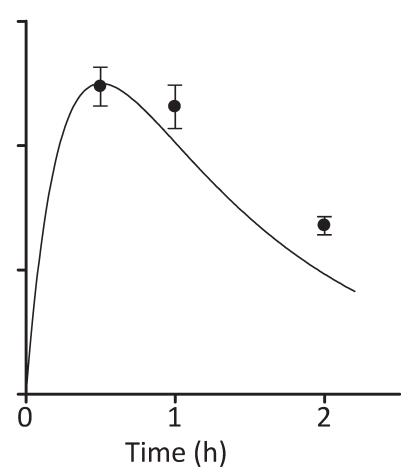

Fig. 3. Changes in Serum HPBCD Concentrations in $\mathrm{Npcl}^{-/-}$Mice

$\mathrm{Npcl}^{-/-}$mice were divided into the following groups (1) $1000 \mathrm{mg} / \mathrm{kg}$ group; (2) $2000 \mathrm{mg} / \mathrm{kg}$ group; and (3) $4000 \mathrm{mg} / \mathrm{kg}$ group. Mice were euthanized $0.5,1$, or $2 \mathrm{~h}$ after HPBCD treatment (subcutaneously) and serum was collected. Simulation curves of serum HPBCD concentrations were estimated by the method of least squares as shown by the solid line. The pharmacokinetic parameters used for the simulation curves were as follows: systemic clearance, $\mathrm{CL}=0.84(\mathrm{~L} / \mathrm{h} / \mathrm{kg}) ; \mathrm{volume}$ of distribution, $206 \mathrm{~mL} /$ $\mathrm{kg}$; and $k_{\mathrm{e}}=4.06 / \mathrm{h}$. Each point represents the mean \pm S.E. $(n=6)$.

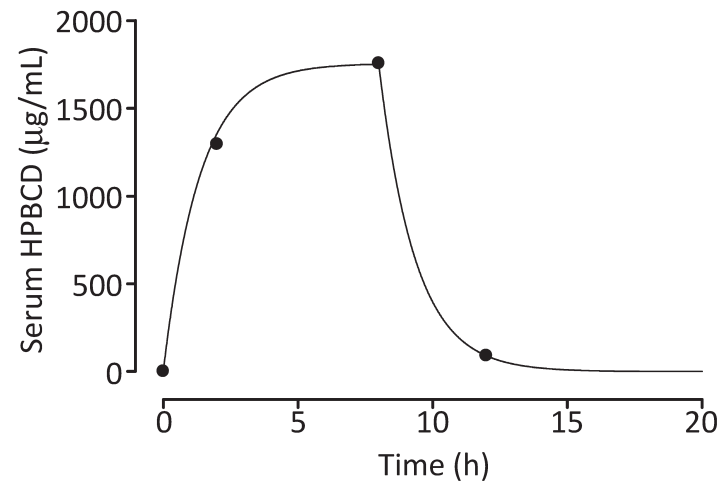

Fig. 4. Changes in Serum HPBCD Concentrations in an NPC Patient

The observed values of serum HPBCD concentrations are shown by the points on the line. The simulation curves of serum HPBCD concentrations were estimated by the method of least squares and are shown by the solid line. The estimated pharmacokinetic parameters of the patient were as follows: systemic clearance, $198 \mathrm{~mL} / \mathrm{h} / \mathrm{kg}$; volume of distribution, $266 \mathrm{~mL} / \mathrm{kg}$; and elimination half-life, $0.92 \mathrm{~h}$.

lesterol content, relative liver weight, and serum ALT activity) were significantly attenuated by $4000 \mathrm{mg} / \mathrm{kg} \mathrm{HPBCD}$ and in $\mathrm{NpCl}^{-1-}$ mice compared with saline-treated mice. In addition, treatment of $2000 \mathrm{mg} / \mathrm{kg}$ HPBCD prevented the increase in unesterified cholesterol content in the liver and serum ALT activity. Aqul et al. ${ }^{15)}$ examined the effective dosage of HPBCD on hepatic cholesterol synthesis activity $24 \mathrm{~h}$ after subcutaneous administration in 7-week-old $\mathrm{Npcl}^{-/-}$mice, and showed that the median effective dose was approximately $200 \mathrm{mg} / \mathrm{kg}$. However, $400 \mathrm{mg} / \mathrm{kg}$ HPBCD-treated mice did not show any significant effects in this study. Based on these results, we consider that $1000 \mathrm{mg} / \mathrm{kg}$ HPBCD or higher is required for improving survival and liver pathophysiological changes in $\mathrm{Npcl}^{-/-}$mice.

Our previous study showed that the maximum nontoxic dose in $\mathrm{Npcl}^{-1-}$ mice is $20000 \mathrm{mg} / \mathrm{kg}$ by a single subcutaneous injection in an acute toxic study. ${ }^{12)}$ In the current study, although total cholesterol content in the liver was normalized with $20000 \mathrm{mg} / \mathrm{kg}$ HPBCD when subcutaneously administered every week, there was no improvement in survival, serum ALT levels, liver/body weight ratio, or liver esterified cholesterol content in $\mathrm{Npcl}^{-1-}$ mice. This lack of finding may be because of the toxicity of multiple administrations of $20000 \mathrm{mg}$ / $\mathrm{kg}$ HPBCD.
In our study, serum HPBCD concentrations at effective dosages $(1000,2000$, and $4000 \mathrm{mg} / \mathrm{kg}$, subcutaneously, once a week) that could improve survival were approximately $0.9-1.8 \mathrm{~mm}(1200-2500 \mu \mathrm{g} / \mathrm{mL})$ at $0.5 \mathrm{~h}$ and $0.3-1.2 \mathrm{~mm}$ $(400-1600 \mu \mathrm{g} / \mathrm{mL})$ at $2 \mathrm{~h}$ after HPBCD injection. Peake and Vance $^{6)}$ showed that 0.1 and $1 \mathrm{mM}$ HPBCD effectively reduced stored cholesterol in isolated primary culture cells from $\mathrm{NpCl}^{-/-}$mice without any cytotoxic action. Tamura and Yui ${ }^{16)}$ also reported similar data in their in vitro experiment using NPC patient-derived dermal fibroblasts. The effective concentrations observed in these in vitro studies appear to be in agreement with those observed in our in vivo study. Based on these results, we suggest that the effective concentration of HPBCD against the NPC disease state is between 0.1-1 mм. However, subcutaneously-injected HPBCD appears to be promptly eliminated from the blood. In this study, the elimination half-life of HPBCD was approximately $1 \mathrm{~h}$. Therefore, HPBCD may be completely cleared within $12 \mathrm{~h}$ after injection of $\mathrm{Npcl}^{-/-}$mice. Aqul et al. ${ }^{15)}$ showed that the elimination half-life of ${ }^{14} \mathrm{C}$-labeled HPBCD $(4000 \mathrm{mg} / \mathrm{kg})$ injected subcutaneously was $1.6 \mathrm{~h}$ in $\mathrm{Npcl}^{-/-}$mice, which is consistent with our results. Some previous reports have also demonstrated that just a single or weekly subcutaneous injection of HPBCD can significantly prolong life-span and improve pathophysiological changes in $\mathrm{Npcl}^{-/-}$mice. $^{7-9,17)}$ These findings suggest that transient increases in HPBCD, rather than maintaining blood levels, is required to exert effectiveness of HPBCD against NPC disease.

Matsuo et $a$ l. $^{4}$ ) showed the effectiveness of intravenous HPBCD therapy in two NPC patients. These patients were treated with approximately $2500 \mathrm{mg} / \mathrm{kg}$ of HPBCD (intravenously administered for $8 \mathrm{~h}$ ) twice per week over 1 year without severe adverse reactions, and hepatosplenomegaly and central nervous dysfunction were improved. In our study, we measured serum HPBCD concentrations during this therapy in one patient. We observed that serum HPBCD concentrations were similar to the effective concentrations observed in in vitro or in vivo. Some previous reports have shown that HPBCD, a cyclic oligosaccharide with high water solubility, is distributed to the extracellular fluid, and is eliminated from blood to urine by renal excretion without hepatic metabolism in rodents and humans. ${ }^{18,19)}$ In our study, the pharmacokinetic 
parameters of HPBCD, such as systemic clearance $(2.89 \mathrm{~L} / \mathrm{h})$ and volume of distribution $(0.26 \mathrm{~L} / \mathrm{kg})$, were in agreement with parameters of physiological function, such as estimated glomerular filtration rate $(2.65 \mathrm{~L} / \mathrm{h})$ and extracellular fluid volume $(0.25 \mathrm{~L} / \mathrm{kg})$, respectively. These results suggest that a large portion of HPBCD is rapidly distributed to the extracellular fluid and excreted at the rate of glomerular filtration in NPC patients, as well as in healthy humans. However, a small portion of HPBCD appears to be incorporated into the intracellular compartment to act as a cholesterol carrier instead of NPC1. ${ }^{20}$ ) Therefore, dose adjustment appears to be required according to renal function to achieve a therapeutic concentration and to avoid toxicity during HPBCD therapy in NPC patients.

Chemical properties, such as the ability for inclusion complex formation, are different among HPBCDs with different DSs. Therefore, information on the DS appears to be important for evaluating the therapeutic effects of HPBCD against NPC manifestation. Lie et al. reported that subcutaneous administration of a single dose $(4000 \mathrm{mg} / \mathrm{kg})$ of HPBCD (average DS of 4.5 or 5.6 ) to $\mathrm{Npcl}^{-/-}$mice at $7 \mathrm{~d}$ of age markedly prolonged lifespan, and no difference was observed between the two HPBCD preparations. ${ }^{7)}$ In some previous studies, HPBCD with DSs of approximately 4.2-5.6 appears to have been used for evaluation of its therapeutic effects on NPC manifestation. ${ }^{7,21,22)}$ Therefore, we used HPBCD with a comparable DS to previous studies in this study. The DS of HPBCD might affect the therapeutic potential against NPC manifestation. In this study, we preliminarily examined the effects of three HPBCD preparations that had different average DSs $(2.8,4.4$, and 7.4) on the cholesterol content in Npcl-deficient cells. Significant differences were not observed among the three preparations on the cholesterol-decreasing effects (Supplemental Fig. 1). Although these results suggest that the difference in DS, at least in the range of approximately 3 to 7, does not affect the therapeutic potential of HPBCD; further study is warranted to clarify this issue.

Although the precise mechanisms of the therapeutic effects of HPBCD against NPC disease are unclear, HPBCD may alter membrane structures within the late endosome/lysosome and improve cholesterol trafficking in NPC1-deficient cells, thus exerting therapeutic potential. ${ }^{23,24)}$ Rosenbaum et al. ${ }^{20)}$ suggested that endocytosed cyclodextrin can reduce cholesterol storage by acting from inside endocytic organelles rather than by removing cholesterol from the plasma membrane. Taylor et al. ${ }^{25)}$ reported that HPBCD did not increase cholesterol in plasma or urine of treated $\mathrm{Npcl}^{-/-}$mice. This finding suggests that HPBCD does not carry sterol from the cell membrane into the bloodstream for ultimate urinary excretion. They also demonstrated that HPBCD promptly decreased the rate of cholesterol synthesis and increased esterified cholesterol levels in tissues of $\mathrm{Npcl}^{-/-}$mice. They advocated that $\mathrm{HPBCD}$ functions in cells of $\mathrm{Npcl}^{-/-}$mice by rapidly liberating lysosomal cholesterol for normal sterol processing within the cytosolic compartment. In our study, we also measured serum free and esterified cholesterol levels after HPBCD or saline treatment in $\mathrm{Npcl}^{-/-}$mice (Supplemental Fig. 2). Although 1000 or $2000 \mathrm{mg} / \mathrm{kg}$ of HPBCD did not show any effects, $4000 \mathrm{mg} / \mathrm{kg}$ or greater of $\mathrm{HPBCD}$ treatment reduced serum free and esterified cholesterol levels in $\mathrm{Npcl}^{-/-}$mice. These changes in serum cholesterol levels were not likely to be a good measure of the therapeutic effect of HPBCD. At least, HPBCD treatment did not increase serum cholesterol levels. Our study results of the changes in serum cholesterol levels are consistent with the results by Taylor et al. ${ }^{25)}$

In this study, information obtained from $\mathrm{Npcl}^{-/-}$mice and in an NPC patient could be useful for HPBCD therapy. However, the present study has the following limitations. First, the appropriate frequency and method of HPBCD administration are unknown. Previous reports have shown that subcutaneous administration of HPBCD $(4000 \mathrm{mg} / \mathrm{kg})$ every week is effective in $\mathrm{Npcl}^{-/-}$mice. $^{7-9,17)}$ In the current study, we found that subcutaneous injection every week of HPBCD could not maintain serum concentrations for a long time, but survival was clearly improved. However, there are no data on the effects of other frequencies of administration (e.g., every day, twice a week, or continuous infusion) of HPBCD. Further study is warranted to evaluate the most effective administration method of HPBCD to achieve the maximum therapeutic potential of HPBCD in $\mathrm{Npcl}^{-/-}$mice and patients. Second, the route of administration of HPBCD was different between animal and human experiments. In our study, the NPC patient was treated with HPBCD by intravenous infusion and serum HPBCD concentrations were determined. However, we evaluated the effective serum concentrations of HPBCD in $\mathrm{Npcl}^{-/-}$mice when administered subcutaneously according to the method of previous reports. ${ }^{7-9,17)}$ Therefore, factors that can affect pharmacodynamics and/or pharmacokinetics of HPBCD, such as the absorption process, should be considered in our data of $\mathrm{Npcl}^{-/-}$mice. The changes in serum HPBCD concentrations tended to be non-linear in the $4000 \mathrm{mg} / \mathrm{kg}$-treated group compared with the 1000 and $2000 \mathrm{mg} / \mathrm{kg}$-treated groups. This finding may be due to saturation and/or inefficient absorption from hypodermal tissue. We administered the HPBCD solution at the same volume among the three groups $(20 \mu \mathrm{L} / \mathrm{g})$. Therefore, the concentration of HPBCD solution used in the $4000 \mathrm{mg} / \mathrm{kg}$-treated group was $150 \mathrm{~mm}$, and this was higher than the concentrations in the 1000 and $2000 \mathrm{mg} / \mathrm{kg}$-treated groups ( 37.5 and $75 \mathrm{~mm}$, respectively). In addition, the viscosity of HPBCD solution in the high-dose groups (4000 and $20000 \mathrm{mg} / \mathrm{kg}$ groups) was likely to be high. We observed gellike formation in hypodermal tissue after treatment with the high doses (4000-20000 mg/kg) in mice (Supplemental Fig. 3). This may also have affected the absorption of HPBCD from hypodermal tissue in $\mathrm{Npcl}^{-/-}$mice. Therefore, further detailed pharmacokinetic studies of HPBCD in $\mathrm{Npcl}^{-/-}$mice are required to resolve this issue.

In summary, this study shows that weekly subcutaneous injection of 1000,2000 , or $4000 \mathrm{mg} / \mathrm{kg}$ HPBCD can improve survival of $\mathrm{Npcl}^{-1-}$ mice. Symptoms of NPC, liver cholesterol sequestration and injury, are significantly attenuated by $4000 \mathrm{mg} / \mathrm{kg}$ in $\mathrm{Npcl}^{-1-}$ mice. Serum HPBCD concentrations at effective dosages are approximately $0.9-1.8 \mathrm{~mm}$ $(1200-2500 \mu \mathrm{g} / \mathrm{mL})$ at $0.5 \mathrm{~h}$ after subcutaneous injection, and blood HPBCD concentrations are immediately eliminated in $\mathrm{Npcl}^{-/-}$mice. In addition, serum HPBCD concentrations with treatment of approximately $2500 \mathrm{mg} / \mathrm{kg}$ HPBCD twice a week in a patient with NPC are consistent with the effective concentrations observed in vivo using $\mathrm{Npcl}^{-/-}$mice. Additionally, systemic clearance and the volume of distribution are in agreement with the glomerular filtration rate and extracellular fluid volume, respectively. Although further studies are required, the pharmacokinetic parameters obtained in this study 
will provide a rational basis for providing an optimal dosage regimen for HPBCD therapy when administered intravenously to NPC patients.

Acknowledgments We are grateful to Yuka Horikoshi, Shiori Takeuji, Yumiko Hirose, Makiko Taguchi, and all of the staff of the Division of Reproductive Engineering, Center for Animal Resources and Development, Kumamoto University, for breeding the mice. We also gratefully acknowledge financial support from the Japan Society for the Promotion of Science (JSPS KAKENHI Grant Numbers 23590642 and 26460221 to Irie T.).

Conflict of Interest Tetsumi Irie, Yoichi Ishitsuka, Muneaki Matsuo, Naomi Nakagata, Keiichi Motoyama, Hidetoshi Arima, and Sakiko Mochinaga received the research grants from the Japan Society for the Promotion of Science. Tetsumi Irie received $\mathrm{HPBCD}$ as a gift from Nihon Shokuhin Kako Co., Ltd. Koki Wada is an employee of Nihon Shokuhin Kako Co., Ltd. Yuta Tanaka, Yusei Yamada, Koki Shiraishi, Yushiro Uchio, Yuki Kondo, Toru Takeo, Taishi Higashi, Katsumi Higaki, and Kousaku Ohno have no conflict of interest in this study.

Supplementary Materials The online version of this article contains supplementary materials.

\section{REFERENCES}

1) Carstea ED, Morris JA, Coleman KG, Loftus SK, Zhang D, Cummings $\mathrm{C}$, Gu J, Rosenfeld MA, Pavan WJ, Krizman DB, Nagle J, Polymeropoulos MH, Sturley SL, Ioannou YA, Higgins ME, Comly M, Cooney A, Brown A, Kaneski CR, Blanchette-Mackie EJ, Dwyer NK, Neufeld EB, Chang TY, Liscum L, Strauss JF 3rd, Ohno K, Zeigler M, Carmi R, Sokol J, Markie D, O'Neill RR, van Diggelen OP, Elleder M, Patterson MC, Brady RO, Vanier MT, Pentchev PG, Tagle DA. Niemann-Pick C1 disease gene: homology to mediators of cholesterol homeostasis. Science, 277, 228-231 (1997).

2) Naureckiene S, Sleat DE, Lackland H, Fensom A, Vanier MT, Wattiaux R, Jadot M, Lobel P. Identification of HE1 as the second gene of Niemann-Pick C disease. Science, 290, 2298-2301 (2000).

3) Vanier MT. Niemann-Pick disease type C. Orphanet J. Rare Dis., 5, 16 (2010).

4) Matsuo M, Togawa M, Hirabaru K, Mochinaga S, Narita A, Adachi M, Egashira M, Irie T, Ohno K. Effects of cyclodextrin in two patients with Niemann-Pick type C disease. Mol. Genet. Metab., 108, 76-81 (2013).

5) Wojtanik KM, Liscum L. The transport of low density lipoproteinderived cholesterol to the plasma membrane is defective in NPC1 cells. J. Biol. Chem., 278, 14850-14856 (2003).

6) Peake KB, Vance JE. Normalization of cholesterol homeostasis by 2-hydroxypropyl-beta-cyclodextrin in neurons and glia from Niemann-Pick C1 (NPC1)-deficient mice. J. Biol. Chem., 287, 9290-9298 (2012).

7) Liu B, Turley SD, Burns DK, Miller AM, Repa JJ, Dietschy JM. Reversal of defective lysosomal transport in NPC disease ameliorates liver dysfunction and neurodegeneration in the $\mathrm{npcl}^{-1-}$ mouse. Proc. Natl. Acad. Sci. U.S.A., 106, 2377-2382 (2009).

8) Davidson CD, Ali NF, Micsenyi MC, Stephney G, Renault S, Dobrenis K, Ory DS, Vanier MT, Walkley SU. Chronic cyclodextrin treatment of murine Niemann-Pick C disease ameliorates neuronal cholesterol and glycosphingolipid storage and disease progression. PLoS ONE, 4, e6951 (2009).
9) Ramirez CM, Liu B, Taylor AM, Repa JJ, Burns DK, Weinberg AG, Turley SD, Dietschy JM. Weekly cyclodextrin administration normalizes cholesterol metabolism in nearly every organ of the Niemann-Pick type $\mathrm{C} 1$ mouse and markedly prolongs life. Pediatr. Res., 68, 309-315 (2010).

10) Yu D, Swaroop M, Wang M, Baxa U, Yang R, Yan Y, Coksaygan T, DeTolla L, Marugan JJ, Austin CP, McKew JC, Gong DW, Zheng W. Niemann-Pick disease type c: induced pluripotent stem cellderived neuronal cells for modeling neural disease and evaluating drug efficacy. J. Biomol. Screen., 19, 1164-1173 (2014).

11) Loftus SK, Morris JA, Carstea ED, Gu JZ, Cummings C, Brown A, Ellison J, Ohno K, Rosenfeld MA, Tagle DA, Pentchev PG, Pavan WJ. Murine model of Niemann-Pick C disease: mutation in a cholesterol homeostasis gene. Science, 277, 232-235 (1997).

12) Tanaka Y, Ishitsuka Y, Yamada Y, Kondo Y, Takeo T, Nakagata N, Higashi T, Motoyama K, Arima H, Matsuo M, Higaki K, Ohno K, Irie T. Influence of $\mathrm{Npcl}$ genotype on the toxicity of hydroxypropyl$\beta$-cyclodextrin, a potentially therapeutic agent, in Niemann-Pick type C disease models. Mol. Genet. Metab. Rep., 1, 19-30 (2014).

13) Frijlink HW, Visser J, Drenth BF. Determination of cyclodextrins in biological fluids by high-performance liquid chromatography with negative colorimetric detection using post-column complexation with phenolphthalein. J. Chromatogr., 415, 325-333 (1987).

14) Szathmary SC. Determination of hydroxypropyl-beta-cyclodextrin in plasma and urine by size-exclusion chromatography with postcolumn complexation. J. Chromatogr., 487, 99-105 (1989).

15) Aqul A, Liu B, Ramirez CM, Pieper AA, Estill SJ, Burns DK, Liu B, Repa JJ, Turley SD, Dietschy JM. Unesterified cholesterol accumulation in late endosomes/lysosomes causes neurodegeneration and is prevented by driving cholesterol export from this compartment. J. Neurosci., 31, 9404-9413 (2011).

16) Tamura A, Yui N. Lysosomal-specific cholesterol reduction by biocleavable polyrotaxanes for ameliorating Niemann-Pick type $\mathrm{C}$ disease. Sci. Rep., 4, 4356 (2014).

17) Lopez AM, Terpack SJ, Posey KS, Liu B, Ramirez CM, Turley SD. Systemic administration of 2-hydroxypropyl- $\beta$-cyclodextrin to symptomatic Npc1-deficient mice slows cholesterol sequestration in the major organs and improves liver function. Clin. Exp. Pharmacol. Physiol., 41, 780-787 (2014).

18) Frijlink HW, Visser J, Hefting NR, Oosting R, Meijer DK, Lerk CF. The pharmacokinetics of beta-cyclodextrin and hydroxypropyl-betacyclodextrin in the rat. Pharm. Res., 7, 1248-1252 (1990).

19) Irie T, Uekama K. Pharmaceutical applications of cyclodextrins. III. Toxicological issues and safety evaluation. J. Pharm. Sci., 86, 147-162 (1997).

20) Rosenbaum AI, Zhang G, Warren JD, Maxfield FR. Endocytosis of beta-cyclodextrins is responsible for cholesterol reduction in Niemann-Pick type C mutant cells. Proc. Natl. Acad. Sci. U.S.A., 107, 5477-5482 (2010).

21) Camargo F, Erickson RP, Garver WS, Hossain GS, Carbone PN, Heidenreich RA, Blanchard J. Cyclodextrins in the treatment of a mouse model of Niemann-Pick C disease. Life Sci., 70, 131-142 (2001).

22) Liu B, Ramirez CM, Miller AM, Repa JJ, Turley SD, Dietschy JM. Cyclodextrin overcomes the transport defect in nearly every organ of NPC1 mice leading to excretion of sequestered cholesterol as bile acid. J. Lipid Res., 51, 933-944 (2010).

23) Rosenbaum AI, Maxfield FR. Niemann-Pick type C disease: molecular mechanisms and potential therapeutic approaches. J. Neurochem., 116, 789-795 (2011).

24) Vance JE, Peake KB. Function of the Niemann-Pick type C proteins and their bypass by cyclodextrin. Curr. Opin. Lipidol., 22, 204-209 (2011).

25) Taylor AM, Liu B, Mari Y, Liu B, Repa JJ. Cyclodextrin mediates rapid changes in lipid balance in $\mathrm{Npcl}^{-/-}$mice without carrying cholesterol through the bloodstream. J. Lipid Res., 53, 2331-2342 (2012). 